\title{
Water use efficiency of fodder beet crops
}

\author{
E. CHAKWIZIRA, J.M. DE RUITER, S. MALEY, S.J. DELLOW, M.J. GEORGE and A.J. MICHEL \\ The New Zealand Institute for Plant \& Food Research Limited, \\ Private Bag 4704, Christchurch, 8140, New Zealand. \\ Emmanuel.Chakwizira@plantandfood.co.nz
}

\begin{abstract}
In New Zealand, summer rainfall is unpredictable and usually insufficient to meet crop water requirements. The impact of water availability on yield potential of fodder beet (Beta vulgaris L.) is unknown. A single year, single site replicated field experiment investigating biomass production, water use (WU) and water use efficiency (WUE) was carried out on a deep Templeton silt loam soil at Lincoln in 2013. The experiment had four water treatments: 1: Rain fed control, 2: Full potential evapotranspiration (ETo replaced weekly, 3: $50 \%$ of ET replaced every 3 weeks and $4: 50 \%$ of $\mathrm{ET}_{\text {o }}$ replaced weekly. Final dry matter (DM) yield differed with treatments, increasing from an average of $24 \mathrm{t} / \mathrm{ha}$ for the rain fed crops and those receiving $50 \%$ of $\mathrm{ET}_{\text {。 }}$ weekly to $28 \mathrm{t} / \mathrm{ha}$ for the full $\mathrm{ET}_{\mathrm{o}}$ replacement crops and those receiving $50 \%$ of $\mathrm{ET}_{0}$ once every 3 weeks. Water use more than doubled with full irrigation compared with the rain fed crops (774 vs $316 \mathrm{~mm}$ ). The WU for the intermediate crops was $483 \mathrm{~mm}$. However, DM yield was higher for the treatment with $50 \%$ of $\mathrm{ET}_{\text {o }}$ replaced every 3 weeks rather than weekly. Water use was related to DM yield and accounted for the observed variation $\left(\mathrm{R}^{2}=0.75\right)$ in final yield. The WUE decreased with water supply, from $80 \mathrm{~kg} \mathrm{DM} / \mathrm{ha} / \mathrm{mm}$ for the rain fed crops to $46 \mathrm{~kg} \mathrm{DM} / \mathrm{ha} / \mathrm{mm}$ for the full $\mathrm{ET}_{\text {o }}$ replacement treatments, and 64 and $57 \mathrm{~kg} \mathrm{DM} / \mathrm{ha} / \mathrm{mm}$ for the $50 \%$ of ET replaced weekly and every 3 weeks, respectively. Similar DM yield and marginal WUE for the full $\mathrm{ET}_{\mathrm{o}}$ treatments and those receiving $50 \%$ of $\mathrm{ET}_{\text {o }}$ replaced every 3 weeks, meant that the most economic WUE was $57 \mathrm{~kg} \mathrm{DM} / \mathrm{ha} / \mathrm{mm}$. Although these results are from a single and site, they suggest that full $\mathrm{ET}_{\text {o }}$ replacement was uneconomic in this type of soil and therefore partial irrigation to $50 \%$ of $\mathrm{ET}_{\mathrm{o}}$ replaced every 3 weeks may be the optimum for this type of soil. It is recommended to investigate similar treatments on shallow and stony soils.
\end{abstract}

Keywords: Beta vulgaris L., evapotranspiration, water use, water use efficiency, water extraction pattern, water extraction depth.

\section{Introduction}

Droughts are a major limitation to crop productivity in the east coast and central North Island regions of
New Zealand (Burrows \& Greenland 1979). Summer rainfall is unpredictable and usually insufficient to meet crop water requirements. For example, in Canterbury,

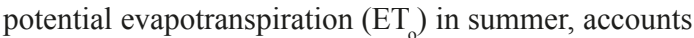
for approximately twice the mean rainfall (Jamieson et al. 1995). Furthermore, most of the soils used for fodder beet (Beta vulgaris L.) production in these areas are shallow and stony with low water holding capacity. In these situations, yield may be compromised when the crop is exposed to extended periods of restricted water availability. There is lack of information on the effects of water supply on fodder beet production in New Zealand, with most of the current recommendation based on data from overseas or other species, e.g. sugar beet (DairyNZ 2013; Brown et al. 1987).

Both fodder beet and sugar beet are sensitive to drought, especially during establishment (Brown et al. 1987; DairyNZ 2013; Martin et al. 1983), but tolerant once the root system has been established. Current recommendations for irrigated fodder beet are to apply irrigation little and often prior to canopy closure and increase both return interval and rate as the season progresses. This encourages deeper and more efficient rooting. However, overwatering in late autumn encourages high humidity under the canopy which can exacerbate leaf diseases and reduce green leaf area. Brown et al. (1987) reported that early drought affected fibrous roots of sugar beet more severely than late drought. Early drought reduced leaf canopy expansion, and consequently, reduced total accumulated radiation intercepted (RI) by the crops, while late drought led to premature senescence of the leaves. Drought reduced radiation use efficiency (RUE; g DM/MJ), from $1.64 \mathrm{~g}$ $\mathrm{DM} / \mathrm{MJ}$ for the fully irrigated crops to 1.37 and $1.51 \mathrm{~g}$ $\mathrm{DM} / \mathrm{MJ}$ for the early and late drought crops, respectively. Consequently, DM yield decreased from $21 \mathrm{t} /$ ha for the fully irrigated crops to $16.1 \mathrm{t} / \mathrm{ha}$ and $17.9 \mathrm{t} / \mathrm{ha}$ for the early and late drought treatments, respectively. Both RI and RUE decreased with water stress. The RI decreased by $8 \%$ for both early and late drought treatments, while RUE decreased by $27 \%$ and $13 \%$ for the early and late drought treatments, respectively, compared with the fully irrigated crops. These results suggests that RUE was the more dominant factors in limiting DM production, a similar conclusion reached for other forage crops, e.g. forage rape (Brassica napus spp. 
Biennis) and bulb turnips (Brassica rapa spp. rapifera; syn. B. campestris) (Chakwizira \& Fletcher 2012).

For other forage crop species, Jacobs et al. (2004a) reported a higher WUE for the rain fed crops: ryegrass (Lolium perenne L.), two brassica species (Hunter, Brassica campestris $x$ Brassica napus and PG545) and millet (Echinochloa utilis) compared with those under full $\mathrm{ET}_{\mathrm{o}}$ replacement and deficit irrigation. Martin et al. (2006) identified $20 \mathrm{~kg} \mathrm{DM} / \mathrm{ha} / \mathrm{mm}$ as an appropriate benchmark for irrigated dairy pastures for Canterbury region of New Zealand. Furthermore, Moot et al. (2008) reported WUE of 7 to $40 \mathrm{~kg} \mathrm{DM} / \mathrm{ha} / \mathrm{mm}$, for a range of pastures in New Zealand, with the high WUE attributed to the application of sufficient N. For forage brassicas species, Jacobs et al. (2004b) reported WUEs of 6-45 $\mathrm{kg} \mathrm{DM} / \mathrm{ha} / \mathrm{mm}$ for forage turnips, while Nielsen et al. (2000) reported WUE of $15-38 \mathrm{~kg} \mathrm{DM} / \mathrm{ha} / \mathrm{mm}$ for four forage brassicas with clear differences between species. The conclusion drawn from these results (Jacobs et al. 2004a, b; Martin et al. 2006; Moot et al. 2008) was that WUE varied with crop species.

Matthew et al. (2011) reported that more precise fodder beet management is required to achieve desired populations $\left(8-10\right.$ plants per $\left.\mathrm{m}^{2}\right)$ and yields than with the traditional winter feeds, e.g. forage brassica crops. However, high yields (19-35 t/ha) and quality of fodder beet make it an attractive and cost effective winter feed option. Previous research in New Zealand has focussed on soil fertility and fertilisers and their effect on DM production and feed quality (Chakwizira et al. 2012, 2013b, 2014; Goh \& Magat 1989; Magat \& Goh 1988). However, the influence of water availability on fodder beet production in New Zealand is still unknown, particularly for the summer dry east coast regions of Canterbury and Otago where most of the crops are grown. The objectives of this experiment were to describe DM response of fodder beet to water deficit, and determine the relative crop water use and water use efficiency under differing irrigation regimes. It is envisioned this knowledge will be used to derive recommendations for optimum soil water management to maximise yield and feed quality for fodder beet crops.

\section{Material and Methods}

The experiment was conducted at The New Zealand Institute for Plant \& Food Research Limited, Lincoln $\left(43.83^{\circ} \mathrm{S}, 171.72^{\circ} \mathrm{E}\right)$, Canterbury, in New Zealand. The site was situated on a deep $(>1.6 \mathrm{~m})$, well drained Templeton silt loam (Immature Pallic soil (Hewitt 2010); Udic Ustochrept (Soil Survey Staff 1998)) with an available water-holding capacity of about $190 \mathrm{~mm} / \mathrm{m}$ of depth (Jamieson et al. 1995). Physical characteristics of the soil were reported by Martin et al. (1992).

The experiment was a randomised block design, with four water treatments, replicated four times. Fodder beet seed (cv. 'Rivage') was direct drilled with an air seeder at 100000 seeds/ha on 29 October 2012, to establish at least 80000 plants/ha. Seeds were sown at a row spacing of $500 \mathrm{~mm}$, which is the standard with sowing contractor machinery. The four water treatments were: 1: Rain fed control, 2: Full potential evapotranspiration $\left(\mathrm{ET}_{\mathrm{o}}\right.$ ) replaced weekly (max $50 \mathrm{~mm}$ per week if no rain), 3: $50 \%$ of $\mathrm{ET}_{\text {o }}$ replaced every 3 weeks $(\max =25 \times 3=75 \mathrm{~mm}$ (if no rain)) and 4: $50 \%$ of $\mathrm{ET}_{\mathrm{o}}$ replaced weekly $(\max =25 \mathrm{~mm}$ (if no rain)). Irrigation was based on cumulative $\mathrm{ET}_{\mathrm{o}}$ at the Broadfield weather station (NIWA 2014) located about $50 \mathrm{~m}$ from the experimental site. The actual amount of water calculated to replace $\mathrm{ET}_{\mathrm{o}}$ was reduced by the amount of rainfall in the period between irrigation events. For treatments 3 and $4,50 \%$ of $\mathrm{ET}_{\mathrm{o}}$ adjusted for rainfall was applied at each irrigation event. The cumulative $\mathrm{ET}_{0}$ for the growing season was $774 \mathrm{~mm}$ and the site received $316 \mathrm{~mm}$ of rainfall during the same period (Figure 1). Irrigation totals for treatments 2, 3 and 4 were 458, 163 and $170 \mathrm{~mm}$, respectively, for the period between sowing and the final harvest. Irrigation treatments were imposed on 6 December 2012 (39 days after sowing; DAS) applying sufficient water to replace full $\mathrm{ET}_{\mathrm{o}}$ (treatment 2) and 50\% of $\mathrm{ET}_{\mathrm{o}}$ (treatments 3 and 4). Plot sizes were $4 \mathrm{~m}$ wide $\times 10 \mathrm{~m}$ long.

The site was prepared by deep ploughing followed by power harrowing. Ten soil samples to $0.15 \mathrm{~m}$ depth were randomly taken on 21 August 2012. Soil test results were: pH 6.3, P $16 \mathrm{mg} / \mathrm{kg}$, Ca $10 \mathrm{mg} / \mathrm{kg}, \mathrm{K} 7 \mathrm{mg} / \mathrm{kg}$, Na $7 \mathrm{mg} / \mathrm{kg}$, S $5 \mathrm{mg} / \mathrm{kg}$ and mineralisable N $79 \mathrm{~kg} / \mathrm{ha}$. Soil nutrients were determined as "MAF quick-test units" (Mountier et al. 1966) and converted into $\mathrm{mg} / \mathrm{kg}$ dry soil using the following conversion factors: $\mathrm{Ca}, \times 125 ; \mathrm{K}, \times 20$; $\mathrm{Mg}, \mathrm{Na}, \times 5 ; \mathrm{P}, \times 1.1$ (Chapman \& Bannister 1994). Basal fertiliser was applied on 29 October 2012 at $250 \mathrm{~kg} /$ ha triple superphosphate $(20.5 \% \mathrm{P}), 350 \mathrm{~kg} /$ ha sodium chloride $(40 \% \mathrm{Na}$ and $60 \% \mathrm{Cl}), 200 \mathrm{~kg} /$ ha potassium chloride $(52 \% \mathrm{~K}$ and $48 \% \mathrm{Cl}), 15 \mathrm{~kg} /$ ha boronate $(10 \%$ B) and $108 \mathrm{~kg} / \mathrm{ha}$ urea $(46 \% \mathrm{~N})$. Additional $\mathrm{N}$ as urea was applied twice, at $50 \mathrm{~kg} \mathrm{~N} / \mathrm{ha}$ on 29 November 2012 and $100 \mathrm{~kg} \mathrm{~N} / \mathrm{ha}$ on 21 December 2012, giving a total of $200 \mathrm{~kg} \mathrm{~N} / \mathrm{ha}$ for the growing season. Weeds, pest and disease were controlled as shown in Table 1.

Environmental data (Figure 1) were collected on-site. Long-term data were obtained from the Broadfields Meteorological Station (NIWA 2014).

\section{Measurements}

Neutron probe (NP) access tubes and Time Domain Reflectometer (TDR) wave guides were installed for the duration of the experiment in each plot following seedling emergence. Volumetric soil water content was measured at 2-weekly intervals from 6 December 2012. 
(a)

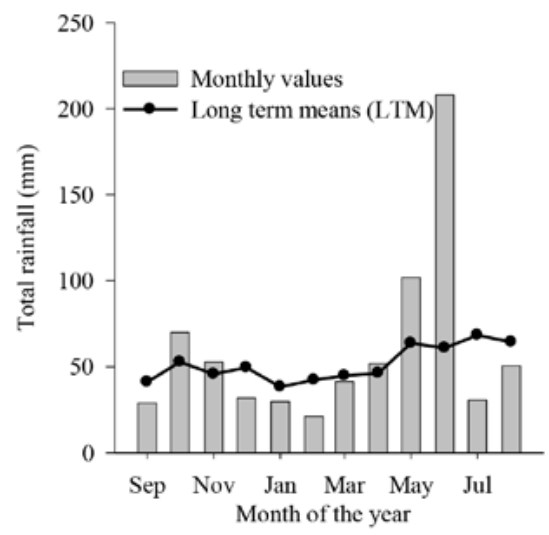

(b)

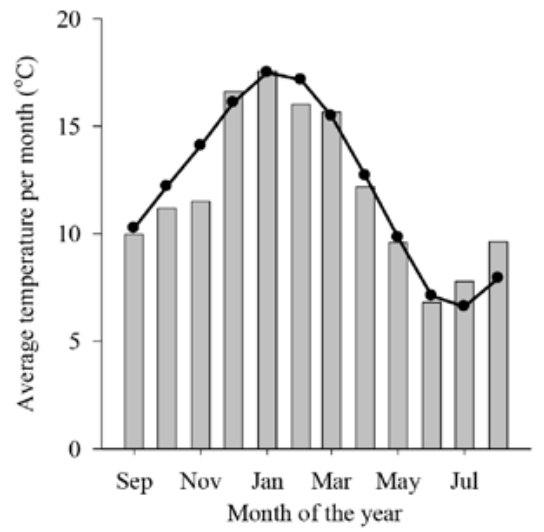

(c)

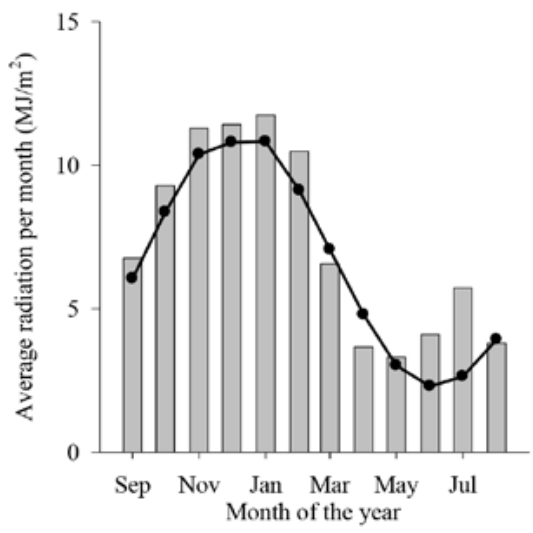

Figure 1 Monthly (a) rainfall $(\mathrm{mm})$, (b) average temperature $\left({ }^{\circ} \mathrm{C}\right)$ and (c) average photosynthetically active radiation (PAR; $\mathrm{MJ} / \mathrm{m}^{2}$ ) for the growing season (September 2012 to August 2013) and long-term mean (LTM) data at Lincoln, Canterbury, New Zealand. Long-term data are from 1970 to 2010 (NIWA 2014).
Measurements were made in $0.2 \mathrm{~m}$ increments to a depth of $1.6 \mathrm{~m}$. The $0-0.2 \mathrm{~m}$ depth was measured using TDR, while all other measurements were made using NP.

Seasonal crop water use (WU) was calculated from volumetric soil water content between the current day and the start of the experiment (29 October 2012), plus any inputs from irrigation and/or rainfall. The WU values reported here included water lost due to transpiration and evaporation. It was assumed that drainage losses were negligible for the soil type of this experiment. The water extraction pattern and cumulative water deficit were determined to $1.6 \mathrm{~m}$ depth for all the treatments. Water extraction pattern was determined for the rain fed treatment alone as irrigation confounded the interpretation of the water extraction in the other treatments (Fletcher et al. 2010). Water use efficiency (WUE; $\mathrm{kg} \mathrm{DM} / \mathrm{ha} / \mathrm{mm}$ ) was calculated as the linear regression of the sequential crop dry matter (DM) measurements plotted against WU for the duration of the experiment. Dry matter data were not available from when soil water measurements were initiated and therefore the linear fits were not forced through the origin. The economic WUE, defined as the ratio of the marketable unit of yield per unit of water used (the cost of the water used) (Dalton 2000; Martin et al. 2006), was based on total amount (irrigation + rainfall) of water recieved. Marginal water use efficiency (MWUE; $\mathrm{kg} \mathrm{DM} / \mathrm{ha} / \mathrm{mm}$ irrigation water) was calculated as the additional DM produced (DM yield minus control (rain fed) DM yield) from applied water (Jacobs et al. 2004a).

Dry matter harvests were taken at 4-weekly intervals from 20 January until 15 May 2013. At the first harvest $1 \mathrm{~m}^{2}$ was harvested per plot and $2 \mathrm{~m}^{2}$ per plot for all subsequent harvests. Plant population and total fresh mass were determined at each harvest. A representative 2-plant subsample was retained to determine \%DM. Subsamples were partitioned into leaf lamina, petiole and bulb. However, DM yield partitioning is reported as shoot (combined petiole and leaf lamina)

Table 1 Herbicides and insecticides applied during establishment of the fodder beet crops grown at Lincoln, Canterbury in 2012-13.

\begin{tabular}{|c|c|c|c|}
\hline Herbicide & Active ingredient ${ }^{1}$ & $\begin{array}{l}\text { Application } \\
\text { rate (/ha) }\end{array}$ & $\begin{array}{l}\text { Date applied } \\
\text { (2012) }\end{array}$ \\
\hline \multirow[t]{4}{*}{ Nortron $^{\circledast}$} & $500 \mathrm{~g} /$ litre ethofumesate (WSC) & 2 litres & 30 October \\
\hline & & $200 \mathrm{ml}$ & 29 November \\
\hline & & $200 \mathrm{ml}$ & 10 December \\
\hline & & $500 \mathrm{ml}$ & 22 December \\
\hline \multirow[t]{3}{*}{ Betanal ${ }^{\circledR}$ Forte } & $160 \mathrm{~g} /$ litre phenmediphan & $500 \mathrm{ml}$ & 29 November \\
\hline & and $160 \mathrm{~g} /$ litre desmediphan (EC) & & 10 December \\
\hline & & 1 litre & 22 December \\
\hline \multirow[t]{3}{*}{ Goltix $^{\circledR}$ DF } & $700 \mathrm{~g} / \mathrm{kg}$ metamotron (WD) & $1 \mathrm{~kg}$ & 29 November \\
\hline & & & 10 December \\
\hline & & & 22 December \\
\hline Lorsban $^{\mathrm{TM}}$ & $50 \%$ chlorpyrifos (EC) & 1 litre & 30 October \\
\hline Gallant $^{\mathrm{TM}}$ Ultra & $520 \mathrm{~g} /$ litre haloxyfop (EC) & $500 \mathrm{ml}$ & 31 December \\
\hline
\end{tabular}

${ }^{1} \mathrm{EC}=$ emulsifiable concentrate, $\mathrm{WSC}=$ water soluble/ suspension concentrate, $\mathrm{WD}=\mathrm{water}$ dispersible 
(a)

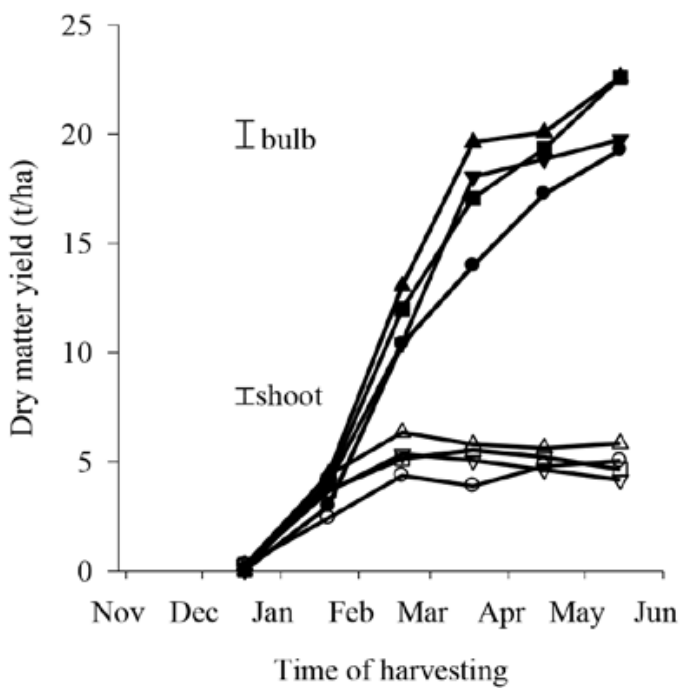

(b)

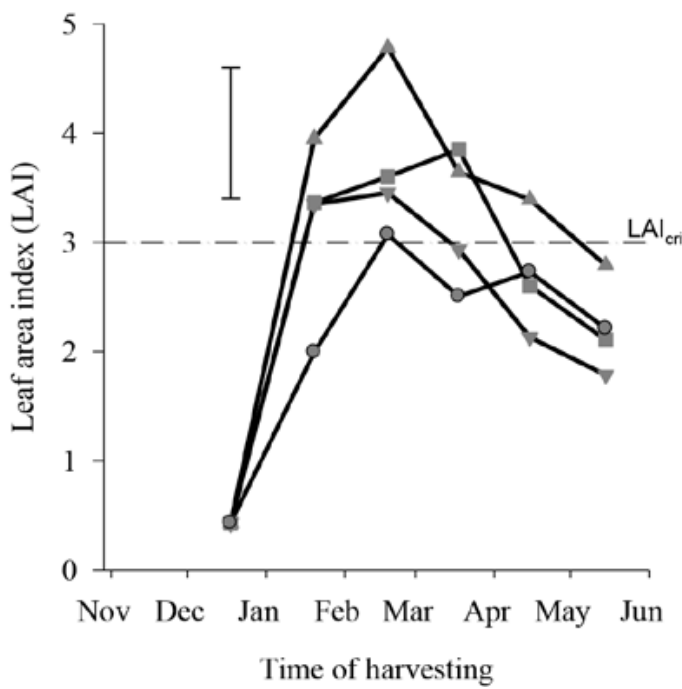

Figure 2 The accumulation of: (a) bulb dry matter yield (black symbols) and shoot dry matter yield (open symbols) and (b) leaf area index (grey symbols) for fodder beet crops grown under different irrigation regimes ( $\mathrm{mm}$ water/ha): Rain fed $(\mathrm{O})$, full $\mathrm{ET}_{\text {。 }}$ replacement $(\triangle), 50 \% \mathrm{ET}_{0}$ replacement every 3 weeks $(\square), 50 \% \mathrm{ET}_{0}$ replacement every week $(\nabla)$ at Lincoln, Canterbury in 2012-13. Vertical bars represent the least significant differences $\left(\operatorname{LSD}_{0.05}\right.$; d.f. $\left.=35\right)$ determined by MANOVA. LAI ${ }_{\text {crit }}=$ critical leaf area index (Martin 1986; Milford et al. 1980).

and bulb for simplicity. Total subsampled leaf lamina was used to determine leaf area, using a leaf area meter (LI-COR model LI-3100; Lincoln, Nebraska, USA) and used to calculate leaf area index (LAI). Dry mass was determined after drying at $60^{\circ} \mathrm{C}$ to constant weight. The accumulated LAI and a critical LAI of 3 (LAI $\mathrm{Lrit}_{\text {: }}: \mathrm{LAI}$ at which the canopy is intercepting $\geq 95 \%$ of the incident radiation; Martin 1986; Milford et al. 1980) was used to describe canopy development over the season. The specific leaf area (SLA) was calculated as the ratio of leaf area $\left(\mathrm{cm}^{2}\right)$ per plant to leaf dry weight (Albayrak \& Çamas 2007; Evans \& Poorter 2001)

Total $\mathrm{N}$ concentration for both the shoot and bulb fractions were determined by the Dumas combustion using a LECO CNS-200 analyser (LECO Corporation, St Joseph, MI). Total $\mathrm{N}$ uptake was then calculated by multiplying plant component DM yield by the concentration of $\mathrm{N}$ in the harvested component. Specific leaf nitrogen (SLN; $g \mathrm{~N} / \mathrm{m}^{2}$ leaf area) was calculated as the quotient of leaf nitrogen content and specific leaf area.

\section{Data analyses}

Data were analysed using multivariate analysis of variance (MANOVA) for repeated measures and analysis of variance (ANOVA) for single measurements. Significant interactions and main effects were separated using Fisher's protected least significant difference (LSD) tests $(\alpha=0.05)$. Where values show $\mathrm{P}<0.1$ a trend is indicated in the text. All analyses were performed in GenStat v.14 (VSN International, Hemel Hampstead, UK) . The regression lines were fitted for the treatment means at each harvest. Water use efficiency parameters (slopes, and intercept) were also calculated per plot and analysed through ANOVA, to confirm comparisons among the treatments. The $\mathrm{R}^{2}$ was used to describe the pooled variation of the dataset from the fitted model.

\section{Results}

At the final harvest, the number of plants was unaffected $(\mathrm{P}=0.27)$ by the irrigation treatments, averaging 86000 plants/ ha. However, dry matter (DM) yield differed $(\mathrm{P}<0.001)$ with treatments, increasing from an average of $24 \mathrm{t} / \mathrm{ha}$ for the rainfed crops and those receiving $50 \%$ of weekly potential evapotranspiration $\left(\mathrm{ET}_{\mathrm{o}}\right)$ to $28 \mathrm{t} / \mathrm{ha}$ for the full $\mathrm{ET}_{0}$ replacement crops and those receiving 50\% replacement of $\mathrm{ET}_{\mathrm{o}}$ once every 3 weeks.

The bulbs represented $79-83 \%$ of total DM yield at the final harvest (Figure 2) and accounted for $99 \%$ of the variation in total DM yield (Figure 3). Between the first harvest (84 DAS) and the final harvest (199 DAS), for every 1 t/ha increase in total DM, the bulb DM increased by $0.91( \pm 0.04) \mathrm{t} / \mathrm{ha}$. Bulb DM yield increased $(\mathrm{P}<0.001)$ from $19.5 \mathrm{t} / \mathrm{ha}$ for the rainfed crops and those receiving $50 \%$ of weekly ET to $22.6 \mathrm{t} / \mathrm{ha}$ for the full $\mathrm{ET}_{\mathrm{o}}$ replacement crops and those receiving 50\% replacement of $\mathrm{ET}_{\mathrm{o}}$ once every 3 weeks. Between 64 and $78 \%$ of the total bulb DM was accumulated between January and March; the period 
(a)

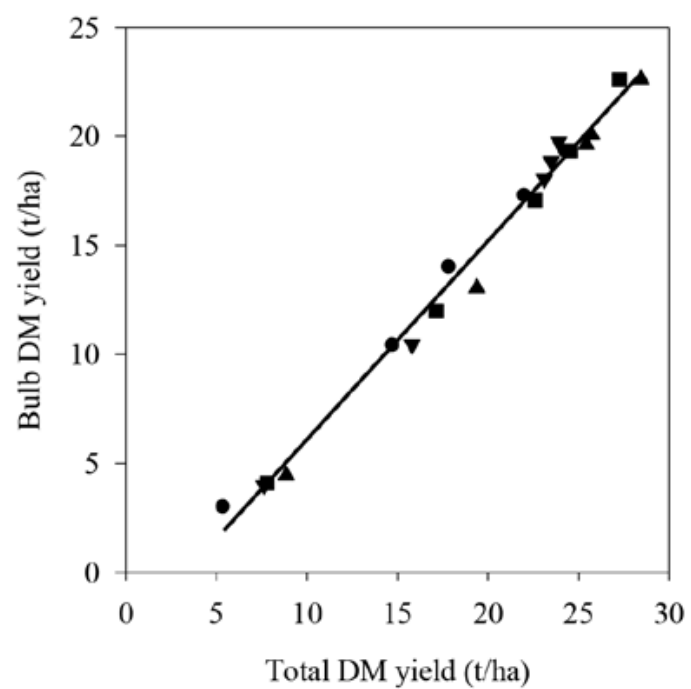

(b)

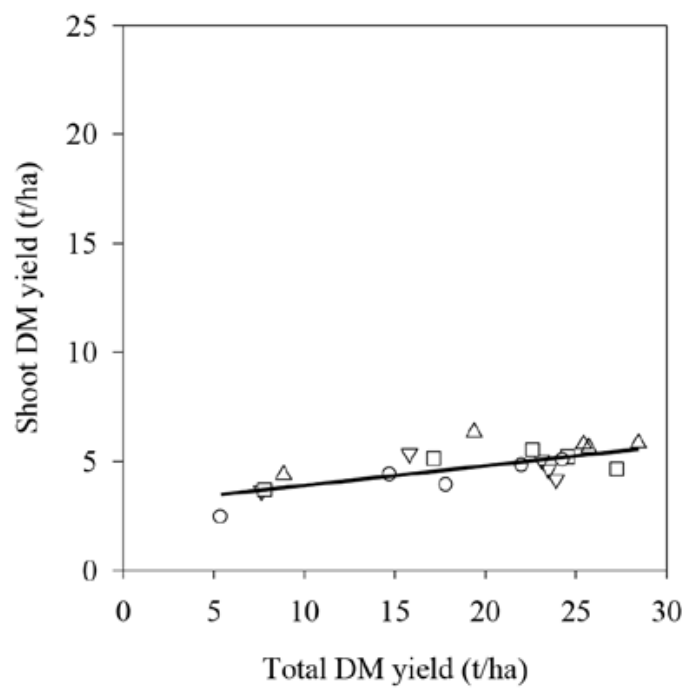

Figure 3 Relationship between (a) bulb $D M$ and total $D M$ yields $\left(Y=0.91( \pm 0.04) x-3( \pm 1.1)\right.$; $\left.R^{2}=0.99\right)$, (b) shoot $D M$ and total $D M$ yield $\left(Y=0.09( \pm 0.04) x+3( \pm 1.4) ; R^{2}=0.49\right)$ for fodder beet crops grown under different water treatments: Rain fed $(O)$, full $\mathrm{ET}_{\text {。 }}$ replacement $(\triangle), 50 \% \mathrm{ET}_{\text {。 }}$ replacement every 3 weeks $(\square), 50 \% \mathrm{ET}_{\text {。 }}$ replacement every week $(\nabla)$ at Lincoln, Canterbury in 2012-13. Bracketed values represent SE for coefficients.

(a)

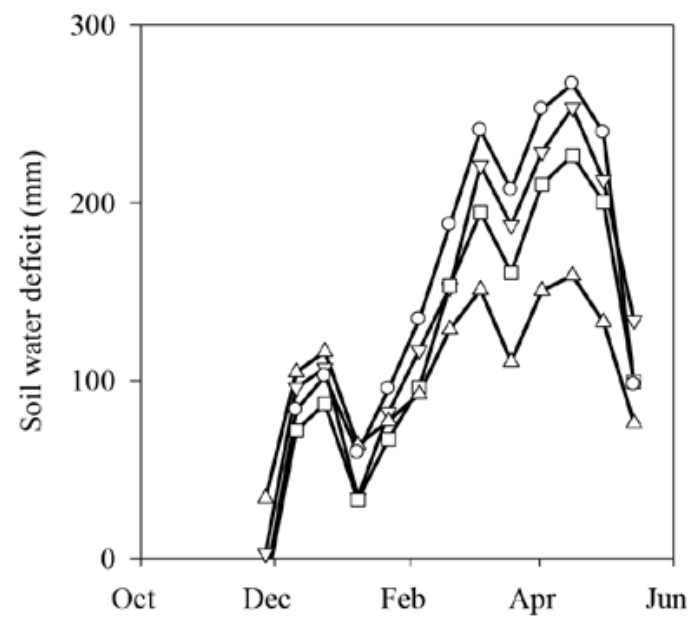

(b)

Water content by depth; $\mathrm{mm}$ at $20 \mathrm{~cm}$ depth increments

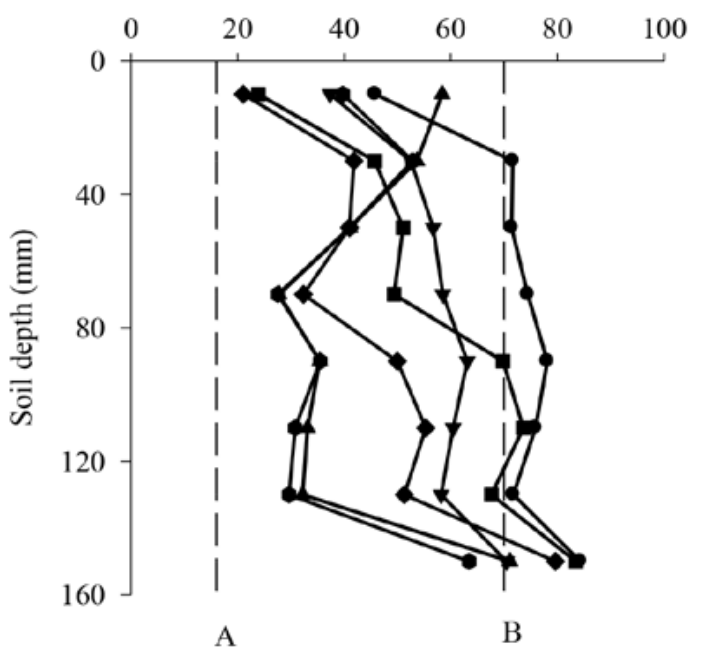

Figure 4 Soil water deficit under a fodder beet crop grown under (a) Rain fed (O), full ET replacement $(\triangle)$, $50 \%$ ET replacement every 3 weeks $(\square)$ or $50 \% \mathrm{ET}_{0}$ replacement every week $(\nabla)$ irrigation treatments and (b) water extraction pattern for the rain fed crop $((\bullet, 27$ November 2012, $\nabla 24$ December, 22 January 2013, 19 February, $\boldsymbol{\Delta} 19$ March and 30 April (dotted lines represent: $A=$ stress point and $B=$ field capacity for this soil)) at Lincoln, New Zealand.

when all irrigated plots were at or above the $\mathrm{LAI}_{\text {crit }}$.

Shoot DM yield increased $(\mathrm{P}<0.001)$ with time until mid-February (118 DAS; Figure 2a), and then declined. During the same period, shoot DM was consistently lower $(\mathrm{P}=0.004)$ for the rain fed crops, compared with the average of the irrigated treatments (which were similar). The LAI for the rain fed crops was consistently below the $\mathrm{LAI}_{\text {crit }}$ throughout the season (Figure 2b). At the final harvest, shoot dry matter represented 17 to $21 \%$ of total DM yield. 


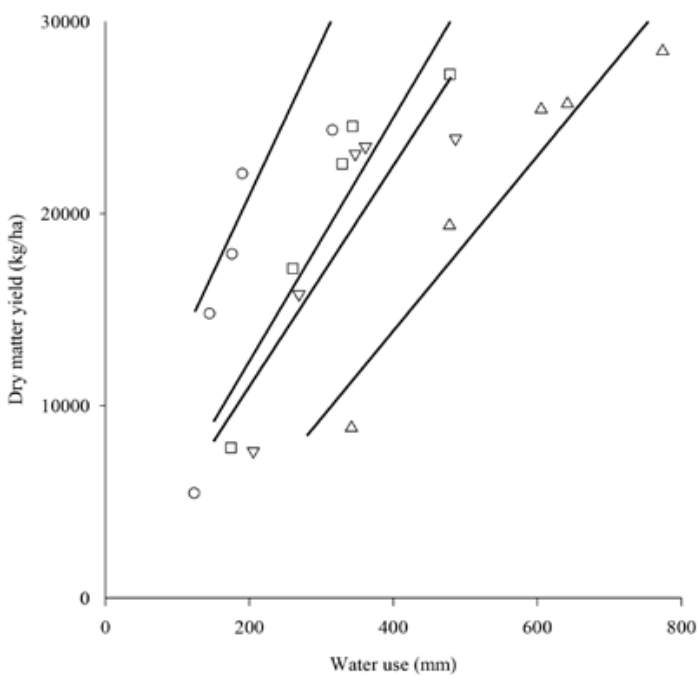

Figure 5 The relationship between dry matter yield $(\mathrm{kg} / \mathrm{ha})$ and water use $(\mathrm{mm})$ for fodder beet crops grown under Rain fed $(O ; Y=80( \pm 24) x+$ $\left.1694( \pm 5587) \quad\left(R^{2}=0.64\right)\right)$, full evapotranspiration $\left(E T_{0}\right)$ replacement $(\triangle ; Y=46( \pm 8) x-4307( \pm 4392)$ $\left.\left(R^{2}=0.92\right)\right), 50 \% E E_{0}$ replacement every 3 weeks $\left(\square ; Y=57( \pm 13) x-505( \pm 4894) \quad\left(R^{2}=0.75\right)\right), 50 \%$ $E T_{0}$ replacement every week $(\nabla ; \mathrm{Y}=64( \pm 14)$ $\left.x-371( \pm 5306)\left(R^{2}=0.86\right)\right)$ conditions at Lincoln, Canterbury in 2012-13. Bracketed values represent SE for coefficients.

The water deficit increased over time (Figure 4a) following the pattern of increasing water demand (Figure 4b). Water deficit was consistently highest in rain fed crops and lowest in those under full $\mathrm{ET}_{\mathrm{o}}$ replacement, e.g. $252 \mathrm{~mm}$ vs $150 \mathrm{~mm}$, respectively, at the end of March. As expected, soil water deficit decreased when it rained. For example, in March the site received $30 \mathrm{~mm}$ of rain on 17 March 2013 and $41 \mathrm{~mm}$ for the month. Total rainfall for December-March was lower than the long term mean (Figure 1) and hence the rapid increases in water deficit under the crops with nil or partial irrigation (Figure 4), e.g. from $60 \mathrm{~mm}$ on 8 January to $253 \mathrm{~mm}$ on 2 April for the rain fed crops.

Water extraction by the rain fed crop is presented in Figure 4b. The crops extracted most of their plant available water to a depth of about $1.4 \mathrm{~m}$ by midMarch. During January to mid-March (Figure 1), water extraction was negligible in the top $0.3 \mathrm{~m}$ of the soil profile. However, after March rainfall, water content increased in the top $0.7 \mathrm{~m}$. The total WU increased (P $<0.001$ ) from $316 \mathrm{~mm}$ for the rain fed plots to $774 \mathrm{~mm}$ for the fully irrigated plots. The $50 \% \mathrm{ET}_{\mathrm{o}}$ replacement treatments used $483 \mathrm{~mm}$.

The water use efficiency (WUE) decreased ( $\mathrm{P}<0.001)$, from $80 \mathrm{~kg} \mathrm{DM} / \mathrm{ha} / \mathrm{mm}$ for the rain fed crops to $46 \mathrm{~kg} \mathrm{DM} / \mathrm{ha} / \mathrm{mm}$ for the plots with full $\mathrm{ET}_{\text {o }}$ replacement (Figure 5). The WUE for the intermediate water treatments were $57 \mathrm{~kg} \mathrm{DM} / \mathrm{ha} / \mathrm{mm}$ for the plots under $50 \% \mathrm{ET}_{\mathrm{o}}$ replacement every 3 weeks and $64 \mathrm{~kg}$ $\mathrm{DM} / \mathrm{ha} / \mathrm{mm}$ for those under $50 \% \mathrm{ET}_{\mathrm{o}}$ replacement every week. These intermediate treatments also differed from the full ET replacement and rain fed plots.

Nitrogen $(\mathrm{N})$ uptake was higher $(\mathrm{P}=0.01)$ for the crops receiving full $\mathrm{ET}_{\mathrm{o}}$ replacement and $50 \% \mathrm{ET}_{\text {o }}$ replaced every 3 weeks at an average of $303 \mathrm{~kg} / \mathrm{ha}$, compared with an average of $255 \mathrm{~kg} / \mathrm{ha}$ for the rain fed crops and those receiving $50 \%$ of ET every week (Table $2)$. The SLA also differed $(\mathrm{P}<0.001)$ with treatments, lowest for the rain-fed crops and highest for the full ET crops. The intermediate treatments had similar SLA values but differed from both the rainfed and full $\mathrm{ET}_{\text {}}$ crops. The SLN was higher $(\mathrm{P}=0.02)$ for the rain fed crops than for all the water treatments.

The MWUE of $18 \mathrm{~kg} \mathrm{DM} / \mathrm{ha} / \mathrm{mm}$ irrigation water for the $50 \%$ replacement of $\mathrm{ET}_{\mathrm{o}}$ once every 3 weeks was higher $(\mathrm{P}=0.07)$ than the $50 \%$ of weekly ET $\mathrm{o}_{0}$ replacement crops, but was similar to the full $\mathrm{ET}_{\mathrm{o}}$ replacement crops.

\section{Discussion}

These results show the importance of water supply on fodder beet production (Figure 2). The increase in DM yield (Figure $2 \mathrm{a}$ ) from about $24 \mathrm{t} / \mathrm{ha}$ for the rainfed crops and those receiving $50 \%$ of weekly $\mathrm{ET}_{0}$ to $28 \mathrm{t} / \mathrm{ha}$ for the full $\mathrm{ET}_{\mathrm{o}}$ replacement crops and those receiving $50 \% \mathrm{ET}_{\mathrm{o}}$ replacement once every 3 weeks was explained by doubling in WU with irrigation from $316 \mathrm{~mm}$ for the

Table 2 Total nitrogen uptake, specific leaf nitrogen (SLN) and specific leaf area (SLA) and marginal water use efficiency (MWUE) for fodder beet crops grown under different water treatments.

\begin{tabular}{|c|c|c|c|c|}
\hline Treatments & $\mathrm{N}$ uptake $(\mathrm{kg} / \mathrm{ha})$ & SLN (g N/m² leaf) & $\operatorname{SLA}\left(\mathrm{cm}^{2} / \mathrm{g}\right)$ & MWUE (kg DM/ha/mm ) \\
\hline Rain fed control & 248 & 2.4 & 148 & $-\mathrm{a}$ \\
\hline $50 \% \mathrm{ET}_{0}$ replaced weekly & 260 & 2.2 & 162 & -2.4 \\
\hline $50 \% \mathrm{ET}_{\mathrm{o}}$ replaced every 3 weeks & 297 & 2.1 & 167 & 18.0 \\
\hline Full weekly $\mathrm{ET}_{\mathrm{o}}$ replaced & 310 & 2.1 & 175 & 9.0 \\
\hline LSD & 36 & 0.2 & 7.5 & 17 \\
\hline
\end{tabular}


rain fed plots to $774 \mathrm{~mm}$ for the fully irrigated plots. This was consistent with findings in other forage crops, e.g. kale (Chakwizira et al. 2013a) where WU increased from $263 \mathrm{~mm}$ for the unirrigated crops to $537 \mathrm{~mm}$ for the fully irrigated crops. The differences in DM yield can also be explained by the differences in $\mathrm{N}$ uptake, SLA and SLN (Table 2) among the respective water treatments.

Water use efficiency (WUE) for fodder beet decreased with irrigation (Figure 5), from $80 \mathrm{~kg} \mathrm{DM} / \mathrm{ha} / \mathrm{mm}$ for the rainfed crops to $46 \mathrm{~kg} \mathrm{DM} / \mathrm{ha} / \mathrm{mm}$ for the full $\mathrm{ET}_{\text {o }}$ replacement crops. This was consistent with findings in other forage crops, e.g. brassica species, ryegrass, and millets (Jacobs et al. 2004a, b), where WUE was highest for the rain fed crops and lowest for the fully irrigated crops. Jacobs et al. (2004a) reported a WUE of $87.8 \mathrm{~kg} \mathrm{DM} / \mathrm{ha} / \mathrm{mm}$ for the rain fed millet compared with $28.1 \mathrm{~kg} \mathrm{DM} / \mathrm{ha} / \mathrm{mm}$ for the fully irrigated millet crops. The WUE for the $50 \%$ of $\mathrm{ET}_{0}$ replaced at weekly and fortnightly intervals, were intermediate at 44.0 and $54.3 \mathrm{~kg} \mathrm{DM} / \mathrm{ha} / \mathrm{mm}$, respectively. The high WUE for rain fed millets was attributed to its ability to utilise water stored in the soil profile. A similar pattern to the results of Jacobs et al. (2004a) was established for the fodder beet in the current experiment. However, previous experiments carried out under a rain-out shelter (which automatically covers the experimental site during rainfall events) under the same environment by Fletcher et al. (2010) and Chakwizira et al. (2013a) reported WUE of 34.1 and $40 \mathrm{~kg} \mathrm{DM} / \mathrm{ha} / \mathrm{mm}$ for kale, respectively. In both experiments, water treatments (variable rates and frequency of irrigation) had no effect on WUE. Furthermore, the WUE values reported in our trial are higher than the $20 \mathrm{~kg} \mathrm{DM} / \mathrm{ha} /$ $\mathrm{mm}$ reported by Martin et al. (2006) for irrigated dairy pastures and 7 to $40 \mathrm{~kg} \mathrm{DM} / \mathrm{ha} / \mathrm{mm}$ (Moot et al. 2008) for a range of pasture species. It is unclear why there are large differences with previously reported results, from the same environment. Neilsen et al. (2000) reported that WUE differed with crop species, double for turnips compared with forage rape and kale. The differences between our results and those previously reported could be attributed to species differences. Fodder beet may have the abiltiy to utilise most of the water stored in the soils or is more efficient user of available water over the summer period, similar to millets (Jacobs et al. 2004a). The ability to utilise stored water is supported by the extraction of water from deeper into the soil profile (Figure 4b).

The MWUE was similar (Table 2) for the high yielding treatment (Figure 2): 50\% $\mathrm{ET}_{\mathrm{o}}$ replaced once every 3 weeks and full $\mathrm{ET}_{0}$ replaced treatments and therefore the economic WUE was $57 \mathrm{~kg} \mathrm{DM} / \mathrm{ha} / \mathrm{mm}$ for the former. This meant that it was not economic to fully irrigate this crop in this type of soil. Even though not statistically different, the MWUE of $9 \mathrm{~kg} \mathrm{DM} / \mathrm{ha} /$ $\mathrm{mm}$ irrigation water for the full $\mathrm{ET}_{\mathrm{o}}$ replacement crops compared with $18 \mathrm{~kg} \mathrm{DM} / \mathrm{ha} / \mathrm{mm}$ irrigation water for the $50 \% \mathrm{ET}_{0}$ replaced once every 3 weeks, meant that it made sense to partially irrigate these crops in these deep soils.

Total water use by crops differed in the respective treatments. Intermediate water treatments had similar WU $(483 \mathrm{~mm})$, but the $50 \% \mathrm{ET}_{\mathrm{o}}$ replaced once every 3 weeks treatments produced more DM yield (ca. 4 t/ ha; Figure 2a) than when ET was replaced weekly. The implication was that the frequency, as well as amount of water applied per irrigation event were important for fodder beet. The WUE was $7 \mathrm{~kg} \mathrm{DM} / \mathrm{ha} / \mathrm{mm}$ higher when a longer return interval was used. The deep, welldrained (Templeton silt loam) soils have a high water holding capacity of $190 \mathrm{~mm} / \mathrm{m}$ depth (Jamieson et al. 1995) and this influenced the way soil water is used. Deficits may occur at the surface while sufficient water is stored at depth. Applying more water per irrigation event raised the root zone soil water to near field capacity (B; Figure 4b). These deep soils were able to hold onto the water for longer periods, due a larger storage capacity and reduced soil evaporation under a closed crop canopy. This also meant that the whole root volume was exposed to adequate moisture and able to take up more nutrients, particularly nitrogen (Brown et al. 1987). This was supported by the differences in nitrogen uptake (Table 2) for the rain fed plots $(248 \mathrm{~kg}$ $\mathrm{N} / \mathrm{ha}$ ), compared with the full $\mathrm{ET}_{\mathrm{o}}$ replacement plots (310 kg N/ha). Chakwizira et al. (2013a) reported that the WUE for kale crops increased with N supply, from $35.3 \mathrm{~kg} \mathrm{DM} / \mathrm{ha} / \mathrm{mm}$ for treatments receiving $\leq 30 \mathrm{~kg} \mathrm{~N} / \mathrm{ha}$ to $40.6 \mathrm{~kg} \mathrm{DM} / \mathrm{ha} / \mathrm{mm}$ for those receiving $\geq 120 \mathrm{~kg} \mathrm{~N} / \mathrm{ha}$. Furthermore, under the longer return intervals, farmers are able to irrigate more paddocks per cycle. However, when less irrigation is applied more frequently (e.g. $50 \% \mathrm{ET}_{\mathrm{o}}$ replaced weekly) the entire root zone may not be entirely refilled in these deep soils, thus crops are continuously under moderate stress and potentially functioning at suboptimal nutrient uptake.

The SLA increased with water supply (Table 2) from a low of $148 \mathrm{~cm}^{2} / \mathrm{g}$ for the rain fed crops to $175 \mathrm{~cm}^{2} / \mathrm{g}$ for the full ET replacement crops. Wilson et al. (1999) reported that low-SLA leaves function more efficiently in resource-poor environments where retention of captured resources is a higher priority, and this may have improved the photosynthetic capacity of the rain fed crops, hence the high DM yield. Moreover, the SLN was highest for the water stressed crops (Table 2). The SLN of 2.1-2.4 g N/m² leaf was consistent with the $2.50-3.15 \mathrm{~g} \mathrm{~N} / \mathrm{m}^{2}$ reported by Chakwizira et al. (2014). The net photosynthesis of crop leaves and/or canopies is closely linked to the SLN (Sinclair \& Horie 1989). Furthermore, the net photosynthesis of a crop can be 
represented by radiation use efficiency (RUE; Monteith, 1977); which decreases when SLN falls below a critical threshold (Sinclair \& Horie 1989). Both the SLA and SLN in this experiment may have contributed to the high DM yield for the rain fed crops.

The water deficit reported for the full $\mathrm{ET}_{\mathrm{o}}$ replacement crops (Figure 4a) could be attributed to the fact that the generic $\mathrm{ET}_{0}$ calculation are based on a well watered grass reference crop (Allen et al. 1998). However, other crops species differ in key factors that affect water loss, such as rooting depth (and water extraction depth), greater for fodder beet at $1.4 \mathrm{~m}$ (Figure $4 \mathrm{~b}$ ) than ryegrass $(0.8-1.1$ m; Parry et al. 1992), and also crop height and canopy cover. This, coupled with the fact that water defit in our experiment was determined to a depth of $1.6 \mathrm{~m}$, meant that we were underestimating the water demand for the fodder beet crops. Usually the taller crops with larger canopies are exposed to more wind and hence increased transpiration. The water extraction depth of about 1.4 $\mathrm{m}$ (Figure $4 \mathrm{~b}$ ) was similar to those reported for other forage crops, e.g. forage brassicas (Chakwizira et al. 2013a; Fletcher et al. 2010) grown at the same site.The rapid increase in accumulated water deficit across the treatments (Figure 4a) until March was due to the dry spell experienced during that time (Figure 1) compared to the long term means. However, as the crops were already established, the dry spell had minimum effects on the rain fed crops in these deep soils, as shown by the DM yield of $24 \mathrm{t} / \mathrm{ha}$.

The DM yields (Figure 2) are consistent with those reported for the Canterbury region of $21-32$ t DM/ ha for irrigated fodder beet (Chakwizira et al. 2012, 2013b, 2014). The proportion of the bulb to total DM yield $(79-83 \%)$ was similar to the range reported by Matthew et al. (2011) and Chakwizira et al. (2013b, 2014). The LAI for the rain fed crops was consistently below the $\mathrm{LAI}_{\text {crit }}$ throughout the season. The decline in LAI (Figure 2a) towards the end of the summer period, particularly for rain fed plots and also in those receiving less water but more frequently, may be associated with premature senescence (Brown et al. 1987) of larger, older leaves under water stress. This finding is consistent with previous reports involving fodder beet (Chakwizira et al. 2014) and other forage crop species (Wilson \& Maley 2006).

\section{Conclusions}

The DM yield increased from $24 \mathrm{t} / \mathrm{ha}$ for the rainfed crops and those receiving $50 \%$ of weekly ET to $28 \mathrm{t} / \mathrm{ha}$ for the full $\mathrm{ET}_{\mathrm{o}}$ replacement crops and those receiving $50 \%$ replacement of ET once every 3 weeks. For the intermediate $(50 \%$ of ET) treatments, DM yield was higher when more water was applied less frequently. The WUE of fodder beet decreased as the quantity of applied irrigation increased, but a higher marginal
WUE for the $50 \% \mathrm{ET}_{\mathrm{o}}$ replaced once every 3 weeks and full $\mathrm{ET}_{\mathrm{o}}$ treatments meant that the economic WUE was $57 \mathrm{~kg} \mathrm{DM} / \mathrm{ha} / \mathrm{mm}$. This was significantly higher than other forage species grown under similar environments. The overall conclusion drawn from this experiment was that, when grown under deep soils with high water holding capacities, it was not be economic to irrigate fodder beet. However, most of the fodder beet crops are grown on shallow soils in Canterbury and Otago regions and therefore irrigation may still be required. It is therefore recommended to investigate similar treatments on shallow and stony soils in Canterbury and/or Otago regions.

\section{ACKNOWLEDGEMENTS}

This work was conducted through the Pastoral 21 Environment Programme (C10X1117; objective 7), jointly funded by MBIE, DairyNZ, Fonterra, and Beef + Lamb New Zealand.

\section{REFERENCES}

Albayrak, S.; Çamas, N. 2007. Effects of temperature and light intensity on growth of fodder beet (Beta vulgaris L. var. Crassa mansf). Bangladesh Journal of Botany 36: 1-12.

Allen, R.G.; Pereira, L.S.; Raes, D.; Smith, M. 1998. Crop evapotranspiration - Guidelines for computing crop water requirements. FAO Irrigation and drainage paper 56. FAO, Rome. file://lindfs $12 /$ home $\$ / \mathrm{Cflexc} /$ My\%20Documents/Evapotransipiration/FAO Paper56.pdf [available online: accessed 18 August 2014]

Brown, K.F.; Messem, A.B.; Dunham, R.J.; Biscoe, P.V. 1987. Effect of drought on growth and water use of sugar beet. The Journal of Agricultural Science 109: 421-435.

Burrows, C.J.; Greenland, D.E. 1979. An analysis of the evidence for climatic change in New Zealand in the last thousand years: Evidence from diverse natural phenomena and from instrumental records. Journal of the Royal Society of New Zealand 9: 321-373.

Chakwizira, E.; de Ruiter, J.M.; Maley, S. 2014. Growth, nitrogen partitioning and nutritive value of fodder beet crops grown under different application rates of nitrogen fertiliser. New Zealand Journal of Agricultural Research 57: 75-89.

Chakwizira, E.; Fletcher, A.L. 2012. Mechanisms of drought response in summer forage brassicas. In: Capturing opportunities and overcoming obstacles in Australian agronomy. Edited by I. Yunusa. Proceedings of 16th Australian Agronomy Conference 2012, 14-18 October 2012. University of New England, Armidale, NSW, Australia. http://www.regional.org.au/au/asa/2012/cropdevelopment/8184_chakwizirae.htm. 
Chakwizira, E.; Gillespie, R.; Maley, S.; George, M.; Michel, A. 2013a. Water and nitrogen use efficiency of forage kale crops. Agronomy New Zealand 43: In Press.

Chakwizira, E.; Maley, S.; George, M.; Hubber, R.; Morton, J.D.; Stafford, A.D. 2012. Effects of potassium, sodium and chloride fertiliser on fodder beet yield and mineral composition. pp. 431-434. In: Proceedings of the 5th Australasian Dairy Science Symposium. Ed. Jacobs, J. 13-15 November 2012, National Dairy Alliance, Melbourne, Australia

Chakwizira, E.; Meenken, E.; Maley, S.; George, M.; Hubber, R.; Morton, J.D.; Stafford, A.D. 2013b. Effects of potassium, sodium and chloride fertiliser rates on fodder beet yield and quality in Canterbury Proceedings of the New Zealand Grassland Association 75: 261-270.

Chapman, H.M.; Bannister, P. 1994. Vegetative production and performance of Calluna vulgaris in New Zealand, with particular reference to Tongariro National Park. New Zealand Journal of Ecology 18: 109-121.

Dalton, P. 2000. Water tight. Whole farm WUE determing your own water security. pp. 395-413. In: Procedings of the 10th Australian Cotton Conference.

DairyNZ 2013. Fodder beet - growing a high yielding crop (1-73) p. 5. http://www.dairynz.co.nz/ media/253800/1-73_Fodder-beet_feeding_to_dairy_ cows.pdf. [available online: accessed 18 August 2014]

Evans, J.R.; Poorter, H. 2001. Photosynthetic acclimation of plants to growth irradiance: the relative importance of specific leaf area and nitrogen partitioning in maximizing carbon gain. Plant, Cell \& Environment 24: 755-767.

Fletcher, A.L.; Sinton, S.M.; Gillespie, R.; Maley, S.; de Ruiter, J.M.; Sim, R.E.; Meenken, E. 2010. Drought response and water use efficiency of forage brassica crops. Proceedings of the Agronomy Society of New Zealand 40: 105-117.

Goh, K.M.; Magat, S.S. 1989. Sodium chloride increases the yield of fodder beet (Beta vulgaris L.) in two New Zealand soils. New Zealand Journal of Agricultural Research 32: 133-137.

Hewitt, A.E. 2010. New Zealand soil classification. Manaaki Whenua - Landcare Research Press, Lincoln, New Zealand, 3rd ed. 136 pp.

Jacobs, J.; Ward, G.N.; McKenzie, F. 2004a. Effect of irrigation strategies on dry matter yields and water use efficiency of a range of forage species. In: Proceedings of the 4th International Crop Science Congress. Ed. Fischer, R. A. 26 September - 1 October 2004, Brisbane, Australia. http://www. cropscience.org.au/icsc2004/poster/1/5/533 jacobsj. htm [available online: accessed 8 February 2014]
Jacobs, J.L.; Ward, G.N.; Kearney, G. 2004b. Effects of irrigation strategies and nitrogen fertiliser on turnip dry matter yield, water use efficiency, nutritive characteristics and mineral content in western Victoria. Australian Journal of Experimental Agriculture 44: 13-26.

Jamieson, P.D.; Martin, R.J.; Francis, G.S. 1995. Drought influence on grain yield of barley, wheat and maize. New Zealand Journal of Crop and Horticultural Science 23: 55-66.

Magat, S.S.; Goh, K.M. 1988. Effects of chloride fertilizers on yield and uptake of chloride, potassium and sodium by fodder beet (Beta vulgaris L.) in two New Zealand soils. The Journal of Agricultural Science 111: 207-216.

Martin, R.J. 1986. Radiation interception and growth of sugar beet at different sowing dates in Canterbury. New Zealand Journal of Agricultural Research 29: 381-390.

Martin, R.J.; Jamieson, P.D.; Wilson, D.R.; Francis, G.S. 1992. Effects of soil moisture deficits on the yield and quality of 'Russet Burbank' potatoes New Zealand Journal of Crop and Horticultural Science 20: 1-9.

Martin, R.J.; Thomas, S.M.; Stevens, D.R.; Zyskowski, R.F.; Moot, D.J.; Fraser, T.J. 2006. Improving water use efficiency on irrigated dairy farms in Canterbury. Proceedings of the New Zealand Grassland Association 68: 155-160.

Martin, R.J.; Stephen, R.C.; Bourdot, G.W.; Goldson, S.L. 1983. A blueprint for high sugar beet yields in Canterbury. Proceedings of the Agronomy Society of New Zealand 13: 55-58.

Matthew, C.; Nelson, N.J.; Ferguson, D.; Xie, Y. 2011. Fodder beet revisited. Proceedings of the Agronomy Society of New Zealand 41: 39-48.

Milford, G.F.J.; Biscoe, P.V.; Jaggard, K.W.; Scott, R.K.; Draycott, A.P. 1980. Physiological potential for increasing yields of sugar beet. pp. 71-83. In: Opportunities for increasing crop yields. Eds. Hurd, R.G.; Biscoe, P V.; Dennis, C. Pitman, London.

Monteith, J.L. 1977. Climate and the efficiency of crop production in Britain. Philosophical Transaction of the Royal Society of London 281: 277-294.

Moot, D.J.; Brown, H.E.; Pollock, K.; Mills, A. 2008. Yield and water use of temperate pastures in summer dry environments. Proceedings of the New Zealand Grassland Association 70: 51-57.

Mountier, N.S.; Griggs, J.L.; Oomen, G.A.C. 1966. Sources of error in advisory soil tests. New Zealand Journal of Agricultural Research 9: 328-338.

Neilsen, J.E.; Rowe, B.A.; Lane, P.A. 2000. Water use efficiency of four irrigated brassica forage crops. pp. 136-139. In: Proceedings of the Irrigation Association of Australia Conference. Ed. Connellan, G.J. 23-25 May 2000, Melbourne Exihibition and Convention Centre, Melbourne, Australia. 
NIWA 2014. Climate database - NIWA. In: http:// www.cliflo.niwa.co.nz. [available online: accessed 8 February 2014]

Parry, F.J.; McKenzie, B.A.; Lucas, R.J. 1992. Productivity and water use of five pasture grasses in Canterbury. Proceedings of the New Zealand Grassland Association 54: 135-138.

Sinclair, T.R.; Horie, T. 1989. Leaf nitrogen, photosynthesis and crop radiation use efficiency. A review. Crop Science. 29: 90-98.

Soil Survey Staff (1998) Keys to soil taxonomy. USDA-NRCS. 8th ed. United Sates Government Print Office, Washington, DC. 328 pp. Retreived on 22 June 2014 from http://www.itc.nl/ rossiter/Docs/ NRCS/RevKeysSoilTax8_02.pdf [available online: accessed 19 August 2014]
Wilson, D.R.; Maley, S. 2006. Nitrogen balance for kale. In: Groundbreaking Stuff. Ed. Turner, N.; Acuna, T. Proceedings of the 13th Australian Agronomy Conference. 10-14 September 2006 Perth, Western Australia. [available online: accessed 8 March 2014]. http://www.regional.org.au/au/asa/2006/poster/ systems $/ 4550$ wilsondr.htm.

Wilson, P.J.; Thompson, K.E.N.; Hodgson, J.G. 1999. Specific leaf area and leaf dry matter content as alternative predictors of plant strategies. New Phytologist 143: 155-162. 